\title{
Protective Effect of Ajuga multiflora BUNGE Extract on Lead Toxicity of Environmental Pollutant
}

\author{
Jai Yun Jung ${ }^{1}$, Hye Sook Jang ${ }^{2}$, and Young Mi Seo ${ }^{3}$ * \\ ${ }^{1}$ Sanbon Hospital, School of Medicine, Wonkwang University, Gunpo 15865, South Korea \\ ${ }^{2}$ Department of Nursing Jeonju University, Jeonju-city 55069, Jeollabukdo, South Korea \\ ${ }^{3}$ Department of Nursing Seonam University, Namwon 55724, South Korea
}

\begin{abstract}
To evaluate the protective effect of Ajuga multiflora BUNGE (AMB) extract on the toxicity of lead acetate (LA), environmental pollutant, cell viability was measured by XTT assay using cultured NIH3T3 fibroblasts. And also, the effect of antioxidant, butylated hydroxytoluene (BHT) on LA-induced cytotoxicity was analysed. For the protective effect of AMB extract on LA-induced cytotoxicity, NIH3T3 fibroblasts were pretreated with 80 or $90 \mu \mathrm{g} / \mathrm{mL}$ of AMB extract for 2 hours before the treatment of LA. And also, the antioxidative effects of AMB extract against LA-induced cytotoxicity were assessed by DPPH-radical scavenging activity, superoxide dismutase (SOD)-like activity and inhibitory activity of lipid peroxidation (LP). In this study, LA significantly decreased cell viability dose-dependently compared with control, and then $\mathrm{XTT}_{50}$ value was determined at $46.1 \mu \mathrm{M}$ of LA. In the effect of BHT against LA-induced cytotoxicity, it effectively prevented toxic effect of LA by the significant increase of cell viability. In the protective effect of AMB extract on LA-induced cytotoxicity, it significantly increased cell viability which was decreased by LA-induced cytotoxicity, and also it showed the antioxidative effects such as DPPH-radical scavenging activity, SOD-like activity and inhibitory activity of LP. From these results, it is suggested that the cytotoxicity of LA is involved in oxidative stress, and AMB extract effectively prevented the cytotoxicity induced by LA via an antioxidative effect. Conclusively, the natural substance such as AMB extract may be alternative resources for the prevention or treatment of diseases related with oxidative stress.
\end{abstract}

Keywords: alternative resources, cytotoxicity, environment, oxidative stress

\section{Introduction}

Heavy metals such as lead and mercury, as an environmental pollutants, cause water and soil pollution, and also serious diseases when a large amount of heavy metals is accumulated in the body. Itai-itai disease caused by cadmium, and Minamata disease caused by mercury are notable examples (Jin and Nordberg, 1986). Lead is a bluish-white tint heavy metal with atomic number 82 , and exists as an oxide, such as lead monoxide ( $\mathrm{PbO})$, or as a salt form, such as lead sulfate $\left(\mathrm{PbSO}_{4}\right)$, in the natural world. Lead is widely used as a material in various fields, for instance, for storage batteries in industrial processes, paint, ceramics, toys as well as printing business (Tiffany et al., 1988). In particular, lead turns to dust or fumes at a high temperature in processes, and thus can be absorbed through skin or respiratory system, and the absorbed

This paper was supported by wonkwang university in 2016.

Received: May 31, 2017, Revised: June 27, 2017, Accepted: July 18, 2017

*Comesponding author: dudn0408@naver.com 
lead moves through blood vessels, damages tissues and organs in the body, and causes lead toxicity (Son and Jung, 2012). Lead poisoning results in various clinical symptoms such as sleep disorders, loss of appetite, and mania, and it is also known to impede hematogenous functions, damage renal functions, and degenerate neural tissues. Moreover, lead particles can easily pass through the blood-brain barrier (BBB), and thus causes serious brain lesions (Busselberg et al., 1991). Although lead poisoning is fatal, effective treatment methods or medicines have not been developed yet. As a treatment for inorganic lead poisoning, lead chelating agents, such as Ca-EDTA or penicillamine are commonly used, and, as a symptomatic treatment, sedatives are administered with vitamins $\mathrm{B}_{1}$ and $\mathrm{B}_{12}$.

Recently, it was reported that some heavy metals such as lead, cadmium, chrome, and mercury create free radicals and cause toxicity when they collapse (Jung et al., 2014a; Song et al., 2002). Oxidative stress caused by free radicals accelerates the lipid peroxidation (LP) of membranes, and also causes the hyperactivity of the N-methyl-D-aspartate (NMDA) receptor, which is closely related to the calcium channel of divalent ions located in cell membranes, degenerating or killing cells (Park et al., 1996). Moreover, free radicals accelerates the secretion of excitatory amino acids (EAAs), and they are also combined with nitric free radicals, which creates a strong toxic substance, peroxinitrite, and causes cytotoxicity (Pellegrini-Giampietro et al., 1990). For these reasons, several attempts have been made to find treatments for lead poisoning focusing on anti-oxidation (Jung et al., 2014b).

It was also reported recently that medicinal herbs or plants contain a significant amount of pharmacologically active substances such as antioxidative, anti-carcinogenic, antitoxic and anti-inflammatory substances (Gao et al., 2002; Oh et al., 2012). Some natural bioactive substances such as phenolic compounds, tannin, and carotenoid were separated and purified (Jung et al., 2008; Li et al., 2007). There are many phenolic compounds including gallic acid, caffeic acid, gentisic acid, and flavonol. Since they show various bioactivities, and have anti-oxidant, anti-carcinogenic, and antibacterial effects, they are widely used to treat a variety of diseases or symptoms (Chung et al., 2009). These various bioactive effects of phenolic compounds are attributable to their molecular structure in which one or more hydroxyl radicals $(-\mathrm{OH})$ are contained. That is, the avidity of hydroxyl radicals with other substances is very strong, and thus they are known as effective anti-oxidant, antitoxic and anti-inflammatory substances (Krizkova et al., 2000).

Ajuga multiflora BUNGE (AMB) is a Labiatae perennial herb, and grows in plains across Korea. AMB is also called as "Baekhacho" or "Baekhagocho" in Korean, and its dark purple flowers bloom mostly in May and June and its fruits are borne in July (Jung et al., 2014b). All the leaves, stems and roots of AMB have long been used as medicines. As they contain a large amount of substances such as caffeic acid, ascorbic acid, ursolic acid and oleic acid, they have been used for symtoms such as swelling, diuresis, headache, and lymphadenitis. In particular, caffeic acid, ascorbic acid, and oleic acid are phenolic compounds like flavonoid, known as an effective antioxidative substance (Gates et al., 2007).

However, there are only few studies on the antioxidative effects of AMB on lead, and thus it is necessary to suggest the results of basic research at the level of cells. Against this backdrop, this study aimed to examine the effects of the AMB extract on the toxicity of lead acetate (LA), an environmental pollutant, through a cell-level experiment, focusing on their antioxidative effects.

\section{Methods}

\section{Production of chemicals}

Materials used in this study, including LA, butylated hydroxytoluene (BHT), dimethylsulfoxide (DMSO), phosphate buffered saline (PBS), DPPH, and linoleic acid were purchased from Sigma (St Louis. MO, U.S.A.). As working culture solutions, 30, 50, 100 and $150 \mathrm{uM}$ hypotonic solution were produced, and they were diluted to the final concentrations of 
LA. Cells were cultured in a minimum essential medium (MEM, Gibco, U.S.A.) that contains $10 \%$ fetal bovine serum (FBS, Gibco, U.S.A.).

2,3-bis-[2-methoxy-4-nitro-5-sulfophenyl]-2H-tetrazolium-5-caboxanilide, disodium salt (XTT, Sigma, U.S.A.) was produced $(50 \mu \mathrm{g} / \mathrm{mL})$ and stored prior to the experiment.

\section{Cell culture}

NIH3T3 fibroblasts were cultured using a modified version of the method used in the study of Kim et al. (2002). Cells cultured in a culture vessel were separated using the enzyme dissociation method and floated in a MEM culture medium. Cells floated in the culture medium were placed in a culture vessel ( $1 \times 10^{5}$ cells per well), and cultured for 72 hours in a thermostat $\left(36^{\circ} \mathrm{C}, 5 \% \mathrm{CO}_{2}\right)$.

\section{Extraction of $A M B$}

AMB was collected and identified in a university's institute of life science and natural resources. The collected plant (including leaves, stems and roots) was washed thoroughly, and dried in a cool and well-ventilated place. The well-dried plant was cut into a certain size, and put in a double zipper plastic bag. The bag was wrapped in foil and stored in a cool and dark place (temperature: $4^{\circ} \mathrm{C}$, humidity: $11 \pm 1 \%$ ). To collect samples, $72.8 \mathrm{~g}$ of the stored plant was crushed and put in a 1,000 $\mathrm{mL}$ round bottom flask. Distilled water, three times of the sample (approximately $220 \mathrm{~mL}$ ) was poured into the flask and heated for 2 hours. The same process was repeated several times, and the extract was centrifuged at 3,000 rpm for 20 minutes. The supernatant fluid was collected and filtered, and concentrated using a low pressure concentration method in a vacuum concentrator. After freezing and dehydrating, a $3.1 \mathrm{~g}$ sample was obtained. The yield rate was $4.3 \%$.

\section{Treatment of LA}

In culture mediums with different concentrations of LA $(20 \sim 50 \mu \mathrm{M})$, cells were cultured for 48 hours, and its effect was measured as cell viability rate.

\section{Measurement of BHT activity}

The cultured NIH3T3 fibroblasts were pre-treated with different concentrations of BHT $(20 \sim 60 \mu \mathrm{M})$ for 2 hours prior to treating with the oxygen free radicals of $\mathrm{H}_{2} \mathrm{O}_{2}(35 \mu \mathrm{M})$. After that, the activity of BHT was measured as cell viability rate.

\section{Treatment of BHT against LA}

The cultured NIH3T3 fibroblasts were pre-treated with different concentrations of BHT ( $40 \mu \mathrm{M}$ and $60 \mu \mathrm{M})$, of which activity is over $50 \%$, for 2 hours prior to treating with the $\mathrm{XTT}_{50}$ concentration of LA. After that, the effect of BHT on LA was measured as cell viability rate.

\section{Treatment of AMB extract}

To assess the effect of the AMB extract on LA, cells were pre-treated with different rates of the ABM extract $(80 \mu \mathrm{g} / \mathrm{mL}$ and $90 \mu \mathrm{g} / \mathrm{mL}$ ) for 2 hours prior to treating with the $\mathrm{XTT}_{50}$ concentration of LA. After that, the effect of the AMB extract on LA was measured as cell viability rate. 


\section{Measurement of cell viability rate}

Based on the method suggested by Mosmann (1983), the cultured NIH3T3 fibroblasts treated with chemicals were added with XTT (10 $\mu \mathrm{L}$ per well) and cultured for 4 hours. After cultivation, they were fixed with DMSO, and their absorbance was measured at $450 \mathrm{~nm}$ using an ELISA reader. The value of $\mathrm{XTT}_{50}$ was calculated using regression equation.

\section{Measurement of DPPH-radical scavenging activity}

Based on the method suggested by Blois (1958), DPPH-radical scavenging activity was measured. To ethanol solutions treated with different concentrations of the sample, a $0.3 \mathrm{mM} \mathrm{DPPH}$ methanol solution $(100 \mu \mathrm{L})$ was added, and treated at room temperature for 30 minutes. After treatment, their absorbance was measured at $517 \mathrm{~nm}$ using an ELISA reader. In measuring DPPH-radical scavenging activity, BHT was the positive control group, and the activity was measured as the percentage difference between the group added with the sample, and the group not added with the sample over the group not added with the sample.

\section{Measurement of SOD-like activity}

Based on the method suggested by Marklund and Marklund (1974), superoxide dismutase (SOD)-like activity was measured, The sample was added with a Tris- $\mathrm{HCl}$ buffer and $10 \mathrm{mM}$ pyrogallol, and treated at $25^{\circ} \mathrm{C}$ for 10 minutes. After treatment, it was reacted with $\mathrm{HCl}$, and its absorbance was measured at $420 \mathrm{~nm}$ using an ELISA reader. The activity was measured with the group treated with BHT as the positive control group. The activity was measured as the percentage difference between the group added with the sample and the group not added with the sample.

\section{Measurement of lipid peroxidation}

Based on the method suggested by Kikuzaki and Nakatani (1993), lipid peroxidation was measured. To the ethanol solution mixed with the sample (3.9 mL), 2.52\% linoleic acid and 0.05 M PBS (pH 7.0) melted in ethanol were added (1.2 $\mathrm{mL}$ ), and the solution was treated at $40{ }^{\circ} \mathrm{C}$ for 24 hours. After treatment, it was treated with ethanol and $30 \%$ ammonium thiocyanate, and added with $0.02 \mathrm{M}$ ferrous chloride $(0.1 \mathrm{~mL})$. The solution was reacted at room temperature. After reaction, its absorbance was measured at $500 \mathrm{~nm}$ using an ELISA reader. Its inhibitory activity was measured as the percentage difference between the control group and the group added with the sample.

\section{Statistical analysis}

One way ANOVA was conducted using SPSS/WIN 18.0 to compare the LA-induced cytotoxicity of the control group with that of other groups, and differences in the activity of BHT, the effect of BHT on LA, the effect of the AMB extract on LA, DPPH-radical scavenging activity, SOD-like activity, and lipid peroxidation. Post-hoc analysis was conducted using Tukey's honest significant difference (HSD). The statistical significance level was $p<.05$.

\section{Results and Discussion}

\section{LA-induced cytotoxicity}

To measure LA-induced cytotoxicity, the cultured cells were treated with different concentrations of LA ( $20 \sim 50 \mu \mathrm{M})$. 
The cell viability rate of the groups treated with different concentrations of LA showed a statistically significant decrease compared to the control group $(p<.000)$, and that the value of $\mathrm{XTT}_{50}$ was shown at $46.1 \mu \mathrm{M}$ (Table 1 ). The results of this study coincide with the results of the study of Son and Jung (2012) that LA increased cytotoxicity in cultured glioma cells. Since the value of $\mathrm{XTT}_{50}$ was $46.1 \mu \mathrm{M}$, lower than $100 \mu \mathrm{M}$, the toxicity of LA was found to be highly toxic according to the toxic criteria suggested by Borenfreund and Puerner (1985). In this study, the decrease in the cell viability rate caused by LA may be attributable to abnormal calcium channel activities caused by the NMDA receptor damaged by LA (Busselberg et al., 1991), or the growth or differentiation of cells suppressed by the inhibited protein synthesis within cells (Kern et al., 1992). However, the cell viability rate was more likely to decrease due to the degeneration of cells caused by the oxidative stress of LA (Jung et al., 2014a).

\section{Measurement of the activity of BHT}

To measure the activity of BHT, the effect of BHT on $\mathrm{H}_{2} \mathrm{O}_{2}$, a type of oxygen free radicals, was examined. It was found that the cell viability rate of the group treated with $35 \mu \mathrm{M} \mathrm{H}_{2} \mathrm{O}_{2}$ was only $35.3 \%(0.06 \pm 0.01)$ of the control group, but that of the group treated with $20 \mu \mathrm{M}$ BHT was $41.2 \%(0.07 \pm 0.02)$ of the control group, which was slightly increased from that of the group treated with $\mathrm{H}_{2} \mathrm{O}_{2}$ only. Meanwhile, the cell viability rate of the groups treated with $40 \mu \mathrm{M}$ and $60 \mu \mathrm{M}$ of BHT was $70.6 \%(0.12 \pm 0.01)$ and $82.4 \%(0.14 \pm 0.03)$ respectively, and both of them showed a statistically significant increase from the group treated with $\mathrm{H}_{2} \mathrm{O}_{2}$ only. In addition, the activity of BHT was highest in the group treated with $60 \mu \mathrm{M}$ of BHT, and followed by the groups treated with $40 \mu \mathrm{M}$, and $20 \mu \mathrm{M}(p<.000)$ (Table 2). The concentrations of $\mathrm{H}_{2} \mathrm{O}_{2}$ and

Table 1. The cytotoxicity of LA and cultured NIH3T3 fibroblasts.

\begin{tabular}{|c|c|c|c|c|}
\hline \multirow{2}{*}{ Concentration of LA (uM) } & XTT assay $(450 \mathrm{~nm})$ & \multirow{2}{*}{$\mathrm{F}$} & \multirow{2}{*}{$p$} & \multirow{2}{*}{ Tukey HSD } \\
\hline & Mean \pm SD & & & \\
\hline Control $^{\mathrm{a}}$ & $0.19 \pm 0.02$ & \multirow{5}{*}{54.68} & \multirow{5}{*}{$.000^{* * *}$} & \multirow{5}{*}{$a>b>c d e$} \\
\hline $20^{\mathrm{b}}$ & $0.15 \pm 0.02$ & & & \\
\hline $35^{\mathrm{c}}$ & $0.12 \pm 0.01$ & & & \\
\hline $50^{\mathrm{e}}$ & $0.09 \pm 0.01$ & & & \\
\hline $46.1\left(\mathrm{XTT}_{50}\right)^{\mathrm{d}}$ & $0.10 \pm 0.02$ & & & \\
\hline
\end{tabular}

$\mathrm{LA}=\mathrm{Lead}$ acetate.

${ }^{* * *} p<.001$.

Table 2. The antioxidative effect of $\mathrm{BHT}$ on $\mathrm{H}_{2} \mathrm{O}_{2}$ in cultured NIH3T3 fibroblasts.

\begin{tabular}{|c|c|c|c|c|}
\hline \multirow{2}{*}{$\begin{array}{l}\text { Concentration of BHT extract } \\
\qquad(\mathrm{uM})\end{array}$} & XTT assay $(450 \mathrm{~nm})$ & \multirow{2}{*}{$\mathrm{F}$} & \multirow{2}{*}{$p$} & \multirow{2}{*}{ Tukey HSD } \\
\hline & Mean \pm SD & & & \\
\hline Control $^{\mathrm{a}}$ & $0.17 \pm 0.02$ & \multirow{5}{*}{47.55} & \multirow{5}{*}{$.000^{* * *}$} & \multirow{5}{*}{$a>d e>b c$} \\
\hline $35 \mu \mathrm{M} \mathrm{H}_{2} \mathrm{O}_{2}^{\mathrm{b}}$ & $0.06 \pm 0.01$ & & & \\
\hline $20^{\mathrm{c}}$ & $0.07 \pm 0.02$ & & & \\
\hline $40^{\mathrm{d}}$ & $0.12 \pm 0.01$ & & & \\
\hline $60^{\mathrm{e}}$ & $0.14 \pm 0.03$ & & & \\
\hline
\end{tabular}

BHT=Butylated hydroxytoluene; $\mathrm{H}_{2} \mathrm{O}_{2}=$ Hydrogen peroxide . ${ }^{* * *} p<.001$. 
BHT used in this study were set based on the study of Park et al. (2012). The results indicate the protective activity of BHT, an antioxidative substance, against the oxidative stress of $\mathrm{H}_{2} \mathrm{O}_{2}$, a type of oxygen free radicals, which, in turn, means the antioxidative activity of BHT. BHT is widely known as an antioxidant like tocopherol or ascorbic acid (Jarvis and Neville, 2000).

\section{The effect of BHT on LA}

To examine correlation between the toxicity of LA and oxidative stress, the effect of BHT on the toxicity of LA was analyzed. The cell viability rate of the group treated with $\mathrm{XTT}_{50}$ of LA was $31.6 \%(0.06 \pm 0.01)$ of the control group, which was a statistically significant decrease. The cell viability of the group treated with $40 \mu \mathrm{M}$ of BHT was $52.6 \%(0.10 \pm 0.02)$, which showed a statistically significant increase compared to the group treated with LA only $(p<.000)$. In addition, that of the group treated with $60 \mu \mathrm{M}$ of BHT was $68.4 \%(0.13 \pm 0.02)$, indivating a statistically significant increase compared to the group treated with LA only. The antioxidative activity of BHT on LA was highest in the group treated with $60 \mu \mathrm{M}$ of BHT, followed by the group treated with $40 \mu \mathrm{M}(p<.000)$ (Table 3). The results indicate the protective activity of BHT, an antioxidative substance, against the toxicity of LA, and they coincide with the results of the study of Jung et al. (2014a) that proved the antioxidative activity of vitamin $\mathrm{E}$ against the toxicity of lead. The studies above indicate that the toxicity of lead is related to oxidative stress.

\section{The effect of AMB extract on LA}

To examine correlation between the AMB extract and LA-induced cytotoxicity, the cultured cells were pre-treated with 80 and $90 \mu \mathrm{g} / \mathrm{mL}$ of the AMB extract, of which cell viability rate was found to be over $70 \%$ (Jung et al., 2014b). The cell viability rate of the group treated with LA $\left(\mathrm{XTT}_{50}\right)$ only was $43.7 \%(0.07 \pm 0.02)$ of the control group $(100 \%, 0.16 \pm 0.02)$, but that of the group treated with $80 \mu \mathrm{g} / \mathrm{mL}$ of the AMB extract was $62.5 \%(0.10 \pm 0.01)$, indicating a statistically significant increase compared to the group treated with LA only $(p<.000)$. In addition, that of the group treated with $90 \mu$ $\mathrm{g} / \mathrm{mL}$ of the AMB extract was $75.0 \%(0.12 \pm 0.01)$, also showing a very statistically significant increase compared to the group treated with LA only. The antioxidative activity of the AMB extract against LA was highest in the group treated with $90 \mu \mathrm{g} / \mathrm{mL}$ of the AMB extract, followed by the group treated with $80 \mu \mathrm{g} / \mathrm{mL}(p<.000)$ (Table 4$)$. The results prove the antioxidative activity of the AMB extract against LA-induced cytotoxicity, which seems to be the result of the protective activity of the AMB extract against the oxidative stress of LA based on the finding of this study that the toxicity of LA is related to oxidative stress.

The results of this study also coincide with the results of the study of Jung et al. (2014b) that proved the antioxidative

Table 3. The effect of BHT on LA in cultured NIH3T3 fibroblasts.

\begin{tabular}{lcccc}
\hline \multicolumn{1}{c}{$\begin{array}{c}\text { Concentration of BHT extract } \\
(\mathrm{uM})\end{array}$} & $\mathrm{XTT}$ assay $(450 \mathrm{~nm})$ & $\mathrm{F}$ & $p$ & Tukey HSD \\
\cline { 2 - 2 } Control $^{\mathrm{a}}$ & Mean \pm SD & & & \\
$\mathrm{LA}^{\mathrm{x}}\left(\mathrm{XTT}_{50}\right)^{\mathrm{b}}$ & $0.19 \pm 0.02$ & & $.000^{* * *}$ & $\mathrm{a}>\mathrm{d}>\mathrm{c}>\mathrm{b}$ \\
$40^{\mathrm{c}}$ & $0.06 \pm 0.01$ & 84.40 & \\
$60^{\mathrm{d}}$ & $0.10 \pm 0.02$ & & \\
\hline
\end{tabular}

BHT=Butylated hydroxytoluene; LA=Lead acetate.

${ }^{* * *} p<.001$. 
Table 4. The effect of AMB extract on LA in cultured NIH3T3 fibroblasts.

\begin{tabular}{|c|c|c|c|c|}
\hline \multirow{2}{*}{$\begin{array}{l}\text { Concentration of AMB extract } \\
\qquad(\mu \mathrm{g} / \mathrm{mL})\end{array}$} & XTT assay $(450 \mathrm{~nm})$ & \multirow{2}{*}{$\mathrm{F}$} & \multirow[b]{2}{*}{$p$} & \multirow{2}{*}{ Tukey HSD } \\
\hline & Mean \pm SD & & & \\
\hline Control $^{\mathrm{a}}$ & $0.16 \pm 0.02$ & \multirow{4}{*}{40.43} & \multirow{4}{*}{$.000^{* * *}$} & \multirow{4}{*}{$a>d>c>b$} \\
\hline $\mathrm{LA}\left(\mathrm{XTT}_{50}\right)^{\mathrm{yb}}$ & $0.07 \pm 0.02$ & & & \\
\hline $80^{\mathrm{c}}$ & $0.10 \pm 0.01$ & & & \\
\hline $90^{\mathrm{d}}$ & $0.12 \pm 0.01$ & & & \\
\hline
\end{tabular}

$\mathrm{AMB}=$ Ajuga multiflora $\mathrm{BUNGE}$ LA=Lead acetate. ${ }^{* * *} p<.001$.

activity of the AMB extract, which is attributable to the anti-oxidants in the extract, such as phenolic compounds like caffeic acid, ascorbic acid and oleic acid (Chung et al., 2009). In this regard, the antioxidative activity of the AMB extract was examined.

\section{DPPH-radical scavenging activity}

The scavenging activity of the AMB extract was measured. The scavenging activity value of the group treated with 80 $\mu \mathrm{g} / \mathrm{mL}$ of the AMB extract was $60.9 \%$ of the control group, and that of the group treated with $90 \mu \mathrm{g} / \mathrm{mL}$ was $69.6 \%$. Both of them showed a statistically significant increase in the scavenging activity compared to the control group $(p<.000)$. These results were $75 \sim 85 \%$ of the scavenging activity value of the positive control group treated with BHT (78.3\%) $(p<.000)$. In addition, there was no significant difference in the antioxidative activity depending on the concentration of BHT and AMB (Table 5). The results indicate the antioxidative activity of the AMB extract can reduce free radicals, which coincides with the results of the study of Jung et al. (2014b) on the free radical scavenging activity of the AMB extract. In general, Labiatae plants like AMB contain a variety of substances that have hydroxyl radicals (-OH) in their molecular structure such as caffeic acid, oridonin, enmein, and trichorabdal. DPPH-radical scavenging activity is an analysis method to quantitatively measure the ability to reduce oxygen free radicals, and known as one of the colormetric analysis methods that can measure antioxidative activity like SOD-like activity or lipid peroxidation analysis methods (Marklund and Marklund, 1974).

\section{SOD-like activity}

The SOD-like activity of the AMB extract was analyzed, and the SOD-like activity of the group treated with $80 \mu \mathrm{g} / \mathrm{mL}$ of the AMB extract was $16.7 \%$ of the control group, indicating a statistically significant increase compared to the control

Table 5. The DPPH-radical scavenging activity of Ajuga multiflora BUNGE extract measured at a wavelength.

\begin{tabular}{lccc}
\hline $\begin{array}{c}\text { Concentrations of AMB extract } \\
(\mu \mathrm{g} / \mathrm{mL})\end{array}$ & $\begin{array}{c}\text { DPPH-radical scavenging activity } \\
(517 \mathrm{~nm}) \% \text { of control }\end{array}$ & F & Tukey HSD \\
\hline $40 \mu \mathrm{MBHT}^{\mathrm{za}}$ & 78.3 & 128.67 & $.000^{* * *}$ \\
$80^{\mathrm{b}}$ & 60.9 & & $\mathrm{abc}$ \\
$90^{\mathrm{c}}$ & 69.6 & \\
\hline
\end{tabular}

$\mathrm{AMB}=$ Ajuga multiflora $\mathrm{BUNGE}$; BHT=Butylated hydroxytoluene.

${ }^{* * *} p<.001$. 
group $(p<.005)$. That of the group treated with $90 \mu \mathrm{g} / \mathrm{mL}$ was $33.3 \%$, also showing a statistically significant increase compared to the control group ( $p<.005$ ) (Table 6). In particular, that of the group treated with $90 \mu \mathrm{g} / \mathrm{mL}$ was the same with that of the positive control group treated with BHT. The results indicate that the AMB extract shows SOD-like activity. In other words, it has functions like SOD which, as an antioxidative enzyme in the body, protects the body, with catalase, from oxidative stress by converting oxygen free radicals into water as the final outcome (Marklund and Marklund, 1974). Therefore, it can be concluded that the AMB extract shows antioxidative activity as well as DPPH-radical scavenging activity.

\section{Lipid peroxidation}

The lipid peroxidation of the AMB extract was measured, and the groups treated with $80 \mu \mathrm{g} / \mathrm{mL}$ and $90 \mu \mathrm{g} / \mathrm{mL}$ of the AMB extract were analyzed. First, the lipid peroxidation of the group treated with LA (XTT ${ }_{50}$ ) only was $114.3 \%$ of the control group. However, that of the groups treated with $80 \mu \mathrm{g} / \mathrm{mL}$ and $90 \mu \mathrm{g} / \mathrm{mL}$ of the AMB extract was $81.0 \%$ and $71.4 \%$ respectively (Table 7). The results indicated that the lipid peroxidation inhibitory activity of the groups treated with $80 \mu \mathrm{g} / \mathrm{mL}$ and $90 \mu \mathrm{g} / \mathrm{mL}$ of the AMB extract was $19.0 \%(p<.005)$ and $28.6 \%(p<.005)$ of the control group respectively, and both of them showed a statistically significant increase. In addition, the lipid peroxidation inhibitory activity was highest in the group treated with $90 \mu \mathrm{g} / \mathrm{mL}$ of the AMB extract, followed by the group treated with $80 \mu \mathrm{g} / \mathrm{mL}$, the control group, and the group treated with LA only. Lipid peroxidation accelerates the oxidation of lipids in membranes through the oxidative stress of oxygen free radicals, and consequently causes damage to membranes, the degeneration of cells, and even the apoptosis of cells (Chen and Lin, 2001). The results of this study indicate that the AMB extract protects membranes from damage caused by the lipid peroxidation of LA, and suppresses the oxidative stress of membranes. The results coincide with the results of the study of Jung et al. (2014b) that reported the effect of the AMB extract on the

Table 6. The SOD-like activity of AMB extract measured at a wavelength.

\begin{tabular}{lcccc}
\hline $\begin{array}{c}\text { Concentrations of AMB extract } \\
(\mu \mathrm{g} / \mathrm{mL})\end{array}$ & $\begin{array}{c}\text { SOD-like activity }(420 \mathrm{~nm}) \% \\
\text { of control }\end{array}$ & F & $p$ & Tukey HSD \\
\hline $40 \mu \mathrm{M} \mathrm{BHT}^{\text {za }}$ & 33.3 & & \\
$80^{\mathrm{b}}$ & 16.7 & 5.25 & $.005^{* *}$ & abc \\
$90^{\mathrm{c}}$ & 33.3 & & & \\
\hline
\end{tabular}

$\mathrm{AMB}=$ Ajuga multiflora $\mathrm{BUNGE}$; $\mathrm{BHT}=$ Butylated hydroxytoluene; $\mathrm{SOD}=$ Superoxide dismutase. ${ }^{* *} p<.01$.

Table 7. The lipid peroxidation activity of AMB extract measured at a wavelength.

\begin{tabular}{lcccc}
\hline \multicolumn{1}{c}{$\begin{array}{c}\text { Concentrations of AMB extract } \\
(\mu \mathrm{g} / \mathrm{mL})\end{array}$} & $\begin{array}{c}\text { Lipid peroxidation activity }(500 \mathrm{~nm}) \\
\text { \% of control }\end{array}$ & $\mathrm{F}$ & $p$ & Tukey HSD \\
\hline $\mathrm{Control}^{\mathrm{a}}$ & 100 & & \\
$\mathrm{LA}^{\mathrm{z}}\left(\mathrm{XTT}_{50}\right)^{\mathrm{b}}$ & 114.3 & 61.29 & $.000^{* * *}$ & $\mathrm{~b}<\mathrm{a}<\mathrm{c}<\mathrm{d}$ \\
$80^{\mathrm{c}}$ & 81.0 & & \\
$90^{\mathrm{d}}$ & 71.4 & & \\
\hline
\end{tabular}

AMB: Ajuga multiflora BUNGE, LA: Lead acetate.

${ }^{* * *} p<.001$ 
suppression of the lactate dehydrogenase (LDH) activity. LDH activity analysis is a method to quantitatively measure the damage to membranes, which increases proportionally to LDH activity (Yamamoto et al., 1983). In this regard, the results of this study prove the antioxidative activity of the AMB extract as well as the DPPH-radical scavenging activity and the SOD-like activity discussed above, and this suggests the possibility of using natural substances like the AMB extract as an alternative substance that can protect cells from toxicity or damage caused by oxidative stress. However, it will be still necessary to conduct studies systematically from various aspects such as cell molecule and signal transduction system in order to identify the mechanism of the bioactivity of natural substances like AMB in detail.

\section{Conclusions}

This study examined the effect of the AMB extract, a Lamiaceae herb, on LA, an environmental pollutant. In addition, DPPH-radical scavenging activity, SOD-like activity, and lipid peroxidation inhibitory activity were examined to analyze the antioxidative activity of the AMB extract. The results showed that LA decreased statistically significantly the cell viability rate of the cultured NIH3T3 fibroblasts proportionally to the concentration of LA, the value of XTT S0 $_{50} 46.1 \mu$ $\mathrm{M}$ in the process, which was found to be highly toxic according to the toxicity criteria suggested by Borenfreund and Puerner (1985). Meanwhile, BHT, a type of anti-oxidant, increased statistically significantly the cell viability rate reduced by the toxic of LA, protecting cells from LA-induced cytotoxicity. The AMB extract also increased statistically significantly the cell viability rate reduced by the toxicity of LA $(p<.000)$, and at the same time showed antioxidative activities such as DPPH-radical scavenging activity, SOD-like activity and lipid peroxidation inhibitory activity. Given the results, it can be concluded that oxidative stress is involved in LA-induced cytotoxicity, and also that the AMB extract can effectively protect cells from LA-induce cytotoxicity with it antioxidative activities. Therefore, it is expected that the analysis of the bioactivity and antioxidative activities of natural substances such as the AMB extract can be utilized to research and develop alternative substances for treatment medicines.

\section{References}

Blois, M.S. 1958. Antioxidant determination by the use of a stable free radical. Nature 26:1199-1200.

Borenfreund, E. and J.A. Puerner. 1985. A simple quantitative procedure using monolayer culture for cytotoxicity assay (HTD/NR-90). Methods Cell Sci. 9(1):7-9.

Busselberg, D., M.L. Evans., H. Rahmann, and D.O. Carpenter. 1991. Lead and zinc block a voltage-activated calcium channel of aplysia neurons. J. Neurophysiol. 65(4):786-795.

Chen, C.Y. and T.H. Lin. 2001. Effects of nickel chloride on human platelets: enhancement of lipid peroxidation, inhibition of aggregation and interaction with ascorbic acids. J. Toxicol. Environ. Health Part A 62(6):431-438. DOI: 10.1080/ 00984100150501169

Chung, U.S., Y.Y. Oh, and Y.M. Seo. 2009. A study on the protective effect of gallic acid in cultured human skin melanoma cells damaged by hydrogen peroxide. J. Korean Soc. People plants Environ. 12(6):65-71.

Gao, N., B.H. Jiang, S.S. Leonard, L. Corum, Z. Zhang, R.J. Roberts, J. Antonini, J.Z. Zheng, D.C. Flynn, V. Castrranova, and X. Shi. 2002. p38 signaling mediated hypoxia-inducible factor $1 \alpha$ and vascular endothelial growth factor induction by Cr(VI) in DU145 human prostate carcinoma cells. J. Biol. Chem. 227(47):45041-45048. DOI: 10.1074/jbc.M202775200

Gates, M.A., S.S. Tworoger, J.L. Hecht, B. Rosner, and S.E. Hankinson. 2007. A prospective study of dietary flavonoid intake and incidence of endothelial ovarian cancer. Int. J. Cancer 121(10):2225-2232. DOI: 10.1002/ijc.22790

Jarvis, J.K. and K. Neville. 2000. Antioxidant vitamins: current and future directions. Nutr. Today 35(6):214-221. 
Jin, T. and G.F. Nordberg. 1986. Cadmium toxicity in kidney cells. Resistance induced by short term pretreatment in vitro and in vivo. Basic Clin. Pharmacol. Toxicol. 58(2):137-143. DOI: 10.1111/j.1600-0773.1986.tb00083.x

Jung, J.Y., Y.H. Oh, S.H. Park, M.Y. Yoon, A.J. Pyo, S.J. Kim, Y.W. Yu, and I.J. Jung. 2014a. Antioxidative and whitening effects of houttuynia cordata extract on lead acetate of hair dye component. J. Investig. Cosmetol. 10(2):99-105.

Jung, J.Y., Y.S. Choi, and K.C. Lee. 2008. Effect of gallic acid on the cytotoxicity of mercury. J. Life Sci. Nat. Resour. Res. 30(2):88-95.

Jung, J.Y., S.K. Oh, S.H. Park, M.I. Yoon, Y.W. Yu, Y.S. Rim, and I.J. Jung. 2014b. Antioxidative effect of Ajuga multiflora BUNGE extract on chromium trioxide, dermatitis inducer in cultured NIH3T3 fibroblast. J. Investig. Cosmetol. 10(1):21-26.

Kern, M., T. Audesirk, and G. Audesirk. 1992. Effects of inorganic lead on the differentiation and growth of cortical neurons in culture. Neurotoxicology 14(2):319-327.

Kikuzaki, H. and N. Nakatani. 1993. Antioxidant effects of some ginger constituents. J. Food Sci. 58(6):1407-1410. DOI: 10.1111/j.1365-2621.1993.tb06194.x

Kim, H.S., Y.S. Lee, S.K. Oh, K.C. Lee, G.M. Lee, J. Lee, S.B. Lee, J.H. Kim, J.K. Yu, Y.S. Kang, S.S. Kim, H.J. Song, and S.T. Park. 2002. Effect of Ramulus et uncus uncariae on glucose oxidase induced toxicity in cultured cerebral neurons. Korean J. Orient. Physiol. Pathol. 16(5):1016-1019.

Krizkova, L., M. Nagy, J. Polonyi, J. Dobias, A. Belicova, D. Grancai, and J. Krajcovic. 2000. Phenolic acids inhibit chloroplast mutagenesis in euglena gracillis. Mutat. Res. Genet. Toxicol. Environ. Mutagen. 469(1):107-114. DOI: 10.1016/S1383-5718(00)00059-0

Li, Y.L., G.P. Gan, H.Z. Zhang, H.Z. Wu, C.L. Li, Y.P. Huang, Y.W. Liu, and J.W. Liu. 2007. A flavonoid glycoside isolated from Smilax china L. rhizome in vitro anticancer cell lines. J. Ethnopharmacol. 113(1):115-124. DOI: 10.1016/j.jep.2007.05.016

Marklund, S. and G. Marklund. 1974. Involvement of the superoxide anion radical in the autoxidation of pyrogallol and a convenient assay for superoxide dismutase. FEBS J. 47(3):469-474. DOI: 10.1111/j.1432-1033.1974.tb03714.x

Mosmann, T. 1983. Rapid colorimetric assay for cellular growth and survival: application to proliferation and cytotoxic assays. J. Immunol. Methods 65(1-2):55-63. DOI: 10.1016/0022-1759(83)90303-4

Oh, Y.L., Y.R. Choi, B.S. Chang, and I.J. Jung. 2012. Antioxidative effect of Portulaca oleracea L. extract on allergic contact dermatitis-induced agent, copper in cultured human skin fibroblasts. J. Investig. Cosmetol. 8(4):243-249.

Park, S.T., K.T. Lim, Y.T. Chung, and S.U. Kim. 1996. Methylmercury-induced neurotoxicity in cerebral neuron culture is blocked by antioxidants and NMDA receptor antagonists. Neurotoxicology 17(1):37-46.

Park, S.T., M.S. Kim, Y.M. Seo, R. Kim, and I.J. Jung. 2012. The protective antioxidative effect of solanum nigrum L. extract against the cytotoxicity of hydrogen peroxide in cultured human dermal fibroblasts. J. Investig. Cosmetol. 8(3):171-177.

Pellegrini-Giampietro, D.E., G. Cheriei, M. Alesiani, V. Carla, and F. Moroni. 1990. Excitatory amino acid release and free radical formation may cooperate in the genesis of ischemia-induced neuronal damage. J. Neurosci. 10(3):1035-1041.

Son, Y.W. and I.J. Jung. 2012. Alleviating effect of Elscholtziae splendense extract on the induced toxicity by lead acetate of hair dye compound in cultured glioma cells. J. Investig. Cosmetol. 8(2):115-120.

Song, H.J., D.H. Ha, K.S. Yoo, S.T. Park, and K.C. Lee. 2002. Effect of Sophorae radix on methylmercury induced myotoxicity in cultured myocardial cells. Korean J. Herbol. 17(2):119-124.

Tiffany-C.E., D.M. Garcia, J.N. Wu, J. Zmudzki, and G.R. Brattpn. 1988. Effects of lead on viability and intercellular metal content of C6 glioma cells. J. Toxicol. Environ. Health 23(2):267-279. DOI: 10.1080/15287398809531112

Yamamoto, M., T. Scima, T. Uozumi, K. Yamada, and T. Kawasaki. 1983. A possible role of lipid peroxidation in cellular damages caused by cerebral ischemia and protective effect of alpha-tocopherol administration. Stroke 14(6):977-982. DOI: 10.1161/01.STR.14.6.977 